of debentures by hindering the corporation in the successful prosecution of its business, particularly in times of crisis. These objections apply of course to the existence of such restrictive covenants rather than their enforcement, and make a strong case from the financial point of view for the complete abolition of such covenants, leaving no form of security intermediate between the mortgage bond and the unsecured debenture. It is, however, for the management to consider these objections when debentures with negative pledge clauses are issued and to weigh them against the possible benefits of clauses purporting to give more safety to holders than a simple promise to pay the face amount of the debenture. It seems both practical and reasonable to urge that holders of debentures be assured by statute that the terms of indentures and covenants in debentures, voluntarily assumed by the issuer, shall mean what they say.

\title{
PROVISIONS FOR NON-ASSENTING CLASSES OF CREDITORS IN BANKRUPTCY REORGANIZATIONS
}

THE power to force small groups of creditors to accept a reorganization plan of which they do not approve is one of the crucial features of the reform embodied in Section 77B of the Bankruptry Act. Subsections (e) (1) and (g) provide that all dissenters shall be bound to accept securities under a plan of reorganization which has been approved as fair and equitable by the court and accepted by two-thirds in amount of each class of creditors and by the holders of a majority of the stock of each class. ${ }^{1}$ Further, Section 77B authorizes the confirmation of a plan which has been found by the court to be fair and equitable even without the consent of two-thirds of a class of creditors on certain conditions. Subsection (b) (5) requires that, for each class of creditors of which less than two-thirds shall accept the plan, adequate protection shall be provided, either (a) by the transfer or retention of the property subject to their claims or liens; or (b) by a sale free of liens at not less than a fair upset price, and the transfer of the liens to the proceeds of

1. Bankruptcy Act $\$ 77 B(e)(1)$, (g), 11 U.S.C. $\$ 207(e)(1)$, (g) (Supp. 1935).

Section 77B also eliminates the necessity of the judicial sale, which was criticized as a useless and merely formal part of the equity procedure. See note 20, infra. And the bankruptcy court under Section 77B takes jurisdiction over all property of the deb:or, wherever situated, thus eliminating the expense and difficulty incident to the appointment of ancillary receivers in each district where property of the debtor was located, as was necessary in equity. See Billig, Corporate Reorganization: Equity vs. Bankruptcy (1933) 17 MINN. L. REv. 237, 255. 
the sale; or (c) by appraisal and payment in cash of the value either of such claims, or, at the creditors' election, of the securities allotted to such claims under the plan; or (d) by such method as will in the opinion of the judge equitably and fairly provide such protection.?

There have been few judicial interpretations of this subsection. Methods (a) and (b), providing for a retention of liens and claims, are hardly open to constitutional objection, for both have long been employed in equity receivership reorganizations. ${ }^{3}$ The first method-sale or retention of the property subject to existing liens-is comparable to the equity practice of effecting a reorganization without disturbing underlying first mortgages; while the second-sale at a fair upset price and transfer of liens to the proceeds of the sale-is the usual means of reorganizing under the equity procedure. Method (d), obviously intended as a catch-all clause, has been described as no "method" at all, and it has been held that it will not be used to deprive a secured creditor of his security unless a substitute of the most undeniable equivalence is given. ${ }^{4}$ This limitation upon the effective scope of method (d), while it seems entirely reasonable, will restrict its potential application considerably.

The third method, (c), providing for discharge of the claims of a nonassenting class of creditors by cash payment of the appraised value of their securities, is an innovation in reorganization procedure ${ }^{5}$ which promises to be of considerable utility in making the reorganization process more effective. But statutory amendment may be necessary if the possibilities of subsection (b) (5) (c) are to be realized, for its constitutionality has been successfully questioned in the lower federal courts. One District Court, in refusing to apply method (c) to the claims of first mortgage bondholders under a plan which it found to be neither fair nor feasible, expressed the view that the subsection did not expressly grant the right "to arbitrarily appraise a whole

2. Bankruptcy Act $\$ 77 B(b)(5), 11$ U. S. C. $\$ 207$ (b) (5) (Supp. 1935).

3. See Gerdes, Prozisions for Dissenting Classes of Credilors in a Plan of Rearganization (1936) 2 CORP. REORG. 407.

4. In re Murel Holding Corp., 75 F. (2d) 941 (C.C.A. 2d, 1935).

5. A similar provision appeared in the railroad reorganization section of the Banlsruptcy Act in its original form. 47 STAT. 1474, 11 U. S. C. $\$ 205($ e) (1934). Section 77 (e) as amended in 1935, 49 STAr. 911, 11 U. S. C. $\$ 205$ (e) (Supp. 1935), however, eliminates this provision and goes further, providing that submission of a plan to a class of creditors shall not be required if the Interstate Commerce Commission and the court determine that the interests of such class "have no value," and the court is empowered to confirm a plan not accepted by two-thirds of a class whose consent would otherwise be required if the court concludes that the plan "make adequate provisions for fair and equitable treatment for the interests or claims of those rejecting it" and that "such rejection is not reasonably justified in the light of the respective rights and interests of those rejecting it and all the relevant facts." See Friendly, Amendment of the Railroad Reorganization Act (1936) 36 CoL. L. REv. 27. Judicial interpretations of either the old or new provisions of Section 77 are lacking. 
class of creditors out of the picture", and that such a grant, if made, would be unconstitutional. ${ }^{6}$ The Circuit Court of Appeals for the Sixth Circuit, in the case of In re Tennessee Publishing Company, ${ }^{7}$ went further and declared the subsection unconstitutional, at least as to secured creditors. In that case, after three successive plans of reorganization had been submitted, each of which was opposed by all interests concerned except a relatively small number of unsecured creditors, the debtor invoked subsection (b) (5), proposing, inter alia, to pay non-assenting bondholders the appraised value of their securities in cash. The court held that the plan was not presented in good faith within the meaning of the statute, in that the proposal was not feasible, 8 and held further, in order to forestall further useless proposals by the debtor, that subsection (b) (5) (c) was invalid under the Fifth Amendment, since it deprived a secured creditor of the right to have the property sold at a public sale at which such creditor could protect his interest by bidding. One judge dissented from the majority's definition of "good faith" but concurred in the holding as to constitutionality.

In each of the two cases construing subsection (b) (5)(c), it seems clear that the constitutional issue was prematurely considered, for in neither case was the proposed plan found by the court to be fair. Without a preliminary finding of fairness as well as feasibility, subsection (b) (5) cannot be applied, and it is difficult to see, under the facts of the Temmessee Publishing Company case, how section (b) (5) (c) could be an immediate threat to any of the dissenting creditors' constitutional rights. ${ }^{0}$

Utility of Subsection (b) (5) (c). As a practical matter, Section 77B will not become a nullity with the invalidation of subsection (b) (5)(c).10 Dissenting creditors, secured and unsecured, may still be bound by a plan affecting their interests if the court finds it fair and equitable, and if it is accepted by two-thirds of their class. On the other hand, a comprehensive reorganization statute should contain some provision for dealing with a class of creditors, the consent of two-thirds of which cannot be obtained. Subsection (b) (5), which covers this case, is ambiguous in that it seems to permit the confirmation of a plan with an unlimited number of classes of creditors still in dissent. It is conceivable, reading subsections (b) (4) and (b) (5) together, that a

6. In re Preble Corp., 12 F. Supp. 1002 (D. Me. 1935).

7. 81 F. (2d) 463 (C.C.A. 6th, 1936), (1936) 84 U. PA. L. Rev. 780, (1936)

5 Fordham L. Rev. 349.

8. Section 77B requires that a plan must be presented in "good faith," and this has been construed as requiring feasibility of the plan as well as honesty of purpose. See Comment (1934) 48 Harv. L. Rev. 283.

9. Cf. Developments in the Law-Reorganization under Section $77 B$ of the Bankruptcy Act (1936) 49 HARv. L. Rev. 1111, 1189. By the admission of the Court, the decision on the constitutional question was not necessary to the disposition of the case. 81 F. (2d) $463,467$.

10. Gerdes, loc. cit. supra note 3. 
plan of reorganization might be moulded and confirmed by the judge without the consent of either creditors or stockholders. ${ }^{11}$ As a practical matter, however, this possibility is limited by the discretion of the courts and their reluctance to formulate a plan for the parties; and further, at least under methods (b) (5) (b) and (c), by the difficulty of raising cash with which to pay off the non-assenting creditors. The subsection could well be amended to describe more clearly the situation toward which it is directed-the case where a small but recalcitrant class of creditors is blocking a reorganization approved by other classes and the court. From the standpoint of the reorganizer some such provision is essential, for otherwise $34 \%$ of any small class of creditors might block a reorganization to which substantially all the other creditors had assented. ${ }^{12}$ While subsection (b) (5) has been at issue in few cases and there are no statistics as to the consequences of its application, the mere threat of its existence may have influenced vould-be dissenters to change their minds.

It may be contended that methods (a) and (b) provided in subsection (b) (5) furnish techniques adequate to deal with recalcitrant creditors, where less than two-thirds of each interested class accept the plan. But sale or retention of the property subject to liens under (a) would be of no service to a corporation in need of having its secured debt structure scaled down. And sale of the property at a fair upset price under (b) involves a return to the expensive formality of a judicial sale. Appraisal has several practical advantages over upset price as a means of measuring creditors' claims, from the point of view both of the creditor and of the debtor. Subsection (b) (5) (c) seems definitely to add to the economy and effectiveness of the reorganization process, and it is worth saving, if the Constitution and the courts will permit.

Constitutionality of Subsction $(b)(5)(c)$. The substitution of onerous duties of active administration ${ }^{13}$ for the traditional role of the judge as passive arbiter of competing claims, effected by Section $77 \mathrm{~B}$, might have been one of the intangible factors influencing the decision in the Temressec Publishing Company case. The appraisal provided under subsection (b) (5)(c), which is the final basis for the satisfaction of the claims of dissenting creditors, carries to an extreme an administrative technique in which judges are reluctant to acquiesce.

11. Legis. (1934) 21 VA. L. Rev. 93, 99.

12. See Swaine, Corporate Reorganization under the Federal Bantruptey Pater (1933) 19 VA. L. REv. 317, 330.

13. It has been suggested that reorganization should be effectuated with the aid of a board of impartial arbitrators acquainted with and trained in business problems. Phillips, A Business Tribunal for Corporate Reorganizations (1933) 11 Harv. Bus. REv. 178. Others, notably the banking interests, oppose excessive judicial supervision of the plan with a view to keeping reorganization under the control of business groups. See Dodd, Reorganization through Bankruptcy: a Remedy for What? (1935) $4 \mathrm{~S}$ Hasv. I. REv. 1100. 
Since the decision of the Supreme Court in the Rock Island case, ${ }^{14}$ there can be little doubt that Section 77B in its general aspects is constitutional as an exercise of the bankruptcy power. In affirming an order enjoining the holder of collateral notes of a railroad, which had petitioned for reorganization under Section 77, from selling the collateral and so causing irreparable loss to the estate, the Court in that case held that Section 77 was a valid law on the subject of bankruptcies, indistinguishable in principle from the prior bankruptcy acts authorizing compositions with creditors. ${ }^{15}$ In view of the similarity between Section 77B and Section 77 as it then stood, the decision is practically controlling as to the constitutionality of the former in its general scope, and subsequent lower court decisions so hold. ${ }^{16}$ The first limitation ever to be placed upon the scope of the federal bankruptcy power was the recent holding in Louisville Joint Stock Land Bank v. Radford ${ }^{17}$ that the impairment of contractual rights by bankruptcy legislation may, under some circumstances, constitute a deprivation of property in violation of the Fifth Amendment.

The validity of subsection (b) (5) (c), however, has not yet been passed upon by the Supreme Court. The ground for holding that provision invalid, on the authority of the Radford case, in In re Tennessee Publishing Company, was that a secured creditor has a substantive property right, impaired by subsection (b) (5) (c), to have either payment of his debt in full or the property subject to the lien-i.e. the right to have the property sold at a public sale and to protect his interest then by bidding in the property. In considering the constitutionality of subsection (b)(5)(c) against the background of the Radford case it may be helpful to examine the customary disposition of the claims of non-assenting creditors in corporate reorganizations, for the circumstances of business and prior equity usage may be decisive here in establishing standards of fairness for purposes of the Fifth Amendment.

Equity Receivership Procedure. In an equity receivership, ${ }^{18}$ reorganization is accomplished through a foreclosure of the first mortgage on the property and a "public" sale of the property free of liens to the new corporation, securities of the new corporation being exchanged for those of the old in ac-

14. Continental Ill. Nat. Bank \& Trust Co. v. Chicago, R. I. \& Pac. Ry., 294 U.S. 648 (1935).

15. 30 Stat. 549 (1898), 11 U. S. C. $\$ 30$ (1934).

16. Campbell v. Alleghany Corp., 75 F. (2d) 947 (C.C.A. 4th, 1935), cert. denied, 296 U.S. 581 (1935); In re Central Funding Corp., 75 F. (2d) 256 (C.C.A. 2d, 1935); Grand Boulevard Inv. Co. v. Strauss, 78 F. (2d) 180 (C.C.A. 8th, 1935); In re Pierce-Arrow Sales Corp., 10 F. Supp. 776 (W.D.N.Y. 1935); In re Hotel Gibson Co., 11 F. Supp. 30 (S.D.Ohio, 1935).

17. 295 U.S. 555 (1935):

18. On equity receivership procedure in general, see Billig, supra note 1; Dodd, supra note 13; Swaine, supra note 12; Rosengerg, Swaine and Walker, Corporate Reorganization and the Federai Court (1924). 
cordance with the plan of reorganization, dissenting creditors being paid off in cash according to their pro rata share of the price realized at the sale. While formally this procedure is similar to that used in foreclosing a unitary mortgage on a farm or city lot, as a practical matter it is much different. A judicial sale of a railroad or a large industrial corporation is necessarily a form, for the large values involved make competitive bidding practically impossible. To protect the insolvent corporation against an unduly low price the equity court sets an upset price below which it will consider no bids. ${ }^{10}$ Outside bids are seldom attracted, for the reorganization committee can turn in the claims deposited with it as a large part of the price, while other bidders must pay cash;20 in any event, potential bidders are aware that the claimants represented by the committee have too great a stake in salvaging their interest in the old corporation to permit its assets to be sold to outsiders at a low figure. Furthermore, an insolvent firm is not often an attractive bargain to outsiders, since claims are rarely cut sufficiently, granted the bargaining power of the creditors, to make the firm's earning prospects imposing. The foreclosure sale, besides removing liens, serves also to define the right of an individual bondholder if he chooses to be paid in cash his pro rata share of the price realized instead of accepting securities under the plan; one of the chief. practical objects of the upset price is to provide a measure for cash payments to dissenting creditors. ${ }^{21}$ In fixing an upset price the court must reconcile the interests of the minority, whose claims are in effect evaluated by such determination, and those of the majority, who must raise cash for the expenses of reorganization and the payment of dissenters. In the majority of cases, the only feasible price is the highest that, in the opinion of the court, will permit the reorganization to succeed;22 and the majority, which can refuse to bid if the price is set too high, obviously has a considerable influence on the price set. $^{23}$ While there has been no institutional study of upset prices, there is good evidence that such prices are usually set low enough to malie it advantageous for most dissenters to accept securities under the plan in preference to cash payment.24 It is clear that setting an upset price for the sale of

19. See Wehle, Railroad Reorganization under Section 77 of the Banlirupley Act: Nero Legislation Stugested (1934) 44 YarE L. J. 197, 213.

20. See Louisville Trust fo. v. Louisville, N.A. \& C. Ry., 174 U.S. 674, 682-3 (1899); Dodd, supra note 13, at 1123; Frank, Some Realistic Refictions on Some Aspects of Corporate Reorganization (1933) 19 VA. L. REv. 541, 554; Swaine, suppos note 12 , at 324.

21. See Weiner, Confficting Functions of the Upset Price in a Corporate Reorganization (1927) 27 CoL. I. REv. 132, 137.

22. Id. at 142.

23. See Frank, supra note 20, at 555, 563-4: Kahn, The New Corporate Re-Organization Statute (1934) 9 J. N. A. Ref. BANER, 11.

24. See Weiner, supra note 21, at 143-5; Sabel, The Corforate Rcorganization Act (1934) 19 MINN. L. REv. 34, 42. 
a large corporation in an equity receivership, where competitive bidding is practically nonexistent, closely resembles at many points an appraisal of the interests of dissenting creditors under subsection (b) (5) (c) of 77B or any of the comparable appraisal statutes. The retention of the formality of a sale has been strongly criticized because it serves to divert the attention of the court from the fairness of the plan, and appraisal of the claims of dissenters has been suggested as a more equitable way to handle the problem even in equity receivership. ${ }^{25}$

A limitation upon the efficacy of the sale to cut off the rights of dissenting creditors is found in the doctrine of the Boyd case ${ }^{26}$ to the effect that no interest in stockholders can be recognized in a plan of reorganization without also recognizing and preserving all prior interests in the property. This doctrine does not, however, require payment in cash to unsecured creditors before stockholders can be allowed participation. ${ }^{27} \mathrm{~A}$ fair offer of securities under a plan has been held sufficient to bind such dissenting creditors. ${ }^{28}$

In the light of this background of reorganization practice in equity receiverships, we may return to the question of the constitutionality of the appraisal and payment in cash of the value of the claims of a non-assenting group of creditors under Section $77 \mathrm{~B}(\mathrm{~b})(5)(\mathrm{c})$. The formulas invoked to settle the propriety of an equitable decree are not dissimilar from those used by the courts in assessing the reasonableness of an act of Congress under the Fifth Amendment. It is not improbable that a reorganization practice which the courts would pass as fair in an equity receivership will also be accepted as within the constitutional limits of due process when embodied in a reorganization statute.

There are two general types of situations in which subsection (b) (5) (c) may be invoked: first, where senior classes of creditors, whose claims are generally secured by liens, are seeking to force a plan upon non-assenting junior classes, usually in an unsecured position, and second, where junior classes are seeking to force a plan upon prior creditors. ${ }^{20}$ The answer to the constitutional question may well be different in the two cases. ${ }^{30}$ While both

25. See Frank, supra note 20 , at $557,713$.

26. Northern Pac. Ry. v. Boyd, 228 U.S. 482 (1913). This holding was foreshadowed in Louisville Trust Co. v. Louisville, N.A. \& C. Ry., 174 U.S. 674 (1899). 27. See Northern Pac. Ry. v. Boyd, 228 U.S. 482, 508 (1913).

28. St. Louis-San Francisco Ry. v. McElvain, 253 Fed. 123 (E.D.Mo. 1918). And the securities offered need not be superior in grade to any that the stockholders may obtain. Kansas City Terminal Ry. v. Central Union Trust Co., 271 U. S. 445 (1926).

29. Each of the cases in which doubt has been cast on the constitutionality of subsection (b) (5) (c) falls within the latter class. The property in each was worth less than the amount of the first mortgage debt, but junior creditors were attempting to buy out the first mortgage bondholders on the basis of an appraisal. In neither case was the plan found to be either feasible or fair, and thus the application of the subsection was not properly involved.

30. See Friendly, supra note 5, at 33. 
secured and unsecured claims are property rights within the protection of the Constitution, ${ }^{31}$ in the past unsecured creditors have been treated with considerably less deference than holders of secured interests.

Unsecured Creditors. Prior to Section 77B, claims of unsecured creditors were reduced and settled without a sale in two instances, aside from their discharge in bankruptcy. Unsecured creditors may be constitutionally forced to accept compositions in bankruptcy, under which a dissenting creditor is deprived of his right to have the debtor's property sold for the satisfaction of his debt, when the composition agreement is accepted by a majority of the creditors and confirmed by the court. ${ }^{32}$ And in equity receivership the formal sale has occassionally been dispensed with as a means of determining the rights of unsecured creditors. In Phipps v. Chicago, Rock Island \& Pacific Railway Compan ${ }^{33}$ a dissenting unsecured creditor was forced, without a sale, to accept securities under a plan which had been accepted by $95 \%$ of the class; and in Coricll v. Morris Whitc, Inc. ${ }^{31}$ it was held that the interests of dissenting creditors could be evaluated without the formality of a sale by an appraisal on the basis of a hypothetical price set by the court as the price which would have been received at a public sale. Since both in compositions in bankruptcy and equity receiverships dissenting unsecured creditors have been held bound where the consent of a substantial number of them has been backed by the approval of the court, it would appear to follow that such creditors may be similarly bound under Section 77B to accept securities offered under a plan of reorganization which has : zen accepted by two-thirds of each class and approved by the court. ${ }^{35}$

While the cases seem to indicate that an unsecured creditor may be deprived of his right to have the debtor's property sold on execution if a substantial

31. See In re Burgh. 7 F. Supp. 184, 185 (A.D.Ill. 1933) (holding constitutional $\$ 74$ of the Bankruptcy Act, 11 U.S.C. \$202, providing for compromise or extension of secured debts by consent of a majority of the creditors): WhanREx, Busiknuprcy in United States History (1935) 157; Rosenberg. Reorganization-The Next Step in Corporate Reorgavizatiox avd the Feueral Colrt (1924) 76; cf. Rosenberg. Phipps v. Chicago, Rock Island \& Pacific Ry. Co. in Corforate Reorganization amd THE Federal Cotri (1924) 134.

32. In re Reiman, 20 Fed. Cas. No. 11, 673 (S. D. N. Y. 1874), aff'd, 20 Fed. Cas. No. 11, 675 (C. C.S. D. X. Y. 1875) ; Wilmot v. Aludge, 103 U.S. 217 (1880) ; Cumberland Glass Mfg. Co. v. DeWitt \& Co., 237 U.S. 447 (1915); Ayyers v. International Trust Co., 273 U.S. 380 (1927).

33. 284 Fed. 945 (C.C.A. Sth, 1922), cert. granted, 261 U.S. 611, dismissed per stipulation, 262 U.S. 762 (1923). See criticism of this case in Harding v. American Sumatra Tobacco Co., 14 F. (2d) 168, 169 (N.D.Ga. 1926). See also Frank, supra note 20 , at 562-3; Rosenberg, op. cit. sipra note 31 , at 124 et seq.

34. 54 F. (2d) 255 (C.C..t. 2d, 1931), rez'd on other grounds sub nom. National Surety Co. v. Coriell, 289 U.S. 126 (1933). See Frank, supra note 20, at 716-18; Swaine, supra note 12 , at 325-6.

35. This provision has been held valid. In re Pierce-Arrov Sales Corp., 10 F. Supp. 770 (W.D.N.Y. 1935). 
number of his class consent, they do not cover the case where such consent is lacking. In an equity receivership there is no requirement of any percentage of consent on the part of the unsecured creditors, who have merely the alternative of accepting securities under the plan or of taking the cash value of their interests as a pro rata part of the upset price. The consent of substantial numbers in equity may be some indication to the court that the plan is not grossly arbitrary, and a practical limit to the number of dissenters to a plan is the fact that those who consent must raise the cash to pay off dissenters. And under the dictum of the Boyd case, where the value of the property is less than the first mortgage debt, unsecured creditors need be given a fair offer of securities under the plan only if stockholders are also allowed to participate.

There seem then to be two practical differences between the equity practice as to unsecured creditors, already approved by the courts, and the appraisal rule under subsection (b) (5)(c). In the first place Section 77B (b) (5) (c) does not specify any percentage of consents required before dissenting creditors will be given the choice of accepting cash under an appraisal or securities under a plan. In equity receiverships "substantial support" of the plan is required; but it seems unlikely that a court would find a plan "fair" within the meaning of $77 \mathrm{~B}(\mathrm{~b})(5)$ if it were not supported by a substantial part of each class, or at least of all classes of creditors, even if two-thirds support by each class cannot be mobilized. In the second place there is no sale under the appraisal method at which creditors may bid to protect their interests. Since an upset price and an appraisal are quite similar as means of valuation, at least in terms of consequences, it would seem that a class of unsecured creditors which has rejected a plan found to be fair is at least as well protected under Section $77 \mathrm{~B}(\mathrm{~b})(5)$ (c), with its possibility of appraisal and payment in cash, as under the equity procedure. Furthermore in the case of unsecured creditors the right to bid at the sale is practically valueless, for prior secured creditors have too large a stake in the old corporation to permit its assets to be sold at a price low enough to attract the bids of junior creditors, who must advance sufficient cash to buy out all prior interests if their bid is to be successful. The changes in equity practice effected by the act in respect to the rights of unsecured creditors seem so slight and so practical that little basis can be discerned for declaring subsection (b) (5) (c) unreasonable within the prohibition of the Fifth Amendment.

From the point of view of procedural due process as a constitutional right, indeed, it may be that under an appraisal statute individual dissenters, whether secured or unsecured, have a greater opportunity to be heard, and even to obstruct the reorganization, than in a reorganization where their payment is fixed as a share of an upset price. The possibility of successful objection on appeal to an upset price fixed by a judge is narrowly limited, especially 
with respect to creditors junior to the class whose mortgage is being foreclosed, for the whole theory of the judicial sale runs counter to its being set aside except for fraud or other extreme cause. ${ }^{30}$ But every appraisal must by definition affect an individual class of claims, probably privileging members of that class to appeal. And while an appeal from such an appraisal would not lie as of right under the Bankruptcy Act ${ }^{37}$ but would be discretionary with the appellate court, ${ }^{38}$ it is likely that the courts would be found ready, if the experience under stockholders' appraisal statutes is a guide, ${ }^{30}$ to review such appraisals, at least as to the proper bases for valuation.

Secured Creditors. In its special application to the claims of secured creditors, as where junior classes seek to put through a plan without the consent of prior mortgage bondholders, the constitutionality of this subsection is more doubtful. Sections 77 and $77 B$ are unique in bankruptcy legislation in their treatment of secured creditors, both in the appraisal provision in question and in the provision for binding dissenting secured creditors by a plan approved by two-thirds of their class and by the court. Under prior bankruptcy statutes, the liens of secured creditors have always survived, the trustee in bankruptcy taking title to the bankrupt's 'property subject to valid liens existing four months prior to the filing of the petition. ${ }^{40}$ But under earlier statutes it was found to be within the power of Congress to permit the bankruptcy court to determine the validity of such liens and to decree the method of their liquidation, ${ }^{21}$ as by sale free of liens and transfer of the liens to the proceeds of the sale, although such procedure may have deprived the creditor of the specific remedy which was provided for him in his contract..3 In spite of inroads of this nature, accepted by the

36. Generally, a sale wiil not be set aside ior mere inadequacy of consideration. See (1933) 42 Yale L. J. 960, 961. But cf. First Nat. Banle v. Flershem, 290 U.S. 504 (1934) (sale set aside as fraudulent conveyance where upset price was far balow scrap value); Suring State Bank v. Giese, 210 Wis. 489,246 N. W. 556 (1933).

37. Appeals as of right are limited to certain specified cases, under which an appenl from an appraisal probably could not be classified. Bankruptcy Act $\$ 25(a) ; 11$ U.S. C. $\S 48$ (a) (Supp. 1935).

38. An appraisal would probably be classified as a "proceeding" in bankruptcy, an appeal from which takes the form of a petition to superintend and revise in matter of lav only. Bankruptcy Act $\$ 24(b), 11$ U. S. C. $\$ 47$ (b) (Supp. 1935).

39. Cf. NEW York Stock Corporation Lav \$2l; Matter of Fulton, 257 N. Y. 487, 178 N. E. 766 (1931).

40. Metcalf v. Barker, 187 U.S. 165 (1902); In re Cyclopean Co., 167 Fed. 971 (C.C.A. 2d, 1909) (secured creditor not relinquishing security holds it against trustee in bankruptcy); Comment (1932) 17 MINN. L. REv. 47.

41. Isaacs v. Hobbs Tie \& Timber Co., 282 U.S. 734 (1931).

42. Van Huffel v. Harkelrode, 284 U.S. 225 (1931).

43. In re Jersey Island Packing Co., 138 Fed. 625 (C.C.A. 9th, 1905) (creditor may be restrained from exercising power of immediate sale under trust deed); In re Hasie, 206 Fed. 789 (N.D. Tex 1913) (same); In re Franlilin Breving Co., 249 Fed. 333 (C.C.A. 2d, 1918) (clause in mortgage giving bondholders right to bid 
courts as changes merely in the remedy rather than in the substantive rights of the creditor, the property subject to liens has always been sold at a public sale at which the creditor might bid to protect his interest. Until recently, provisions for compositions in bankruptcy had not been extended to secured creditors $;^{44}$ and Section 74 of the Bankruptcy Act, ${ }^{45}$ which authorizes an extension of time for payment of secured debts upon consent of a majority in number and amount of all creditors, expressly provides that such extension or composition shall not reduce the amount of or impair the liens of secured creditors. ${ }^{46}$

In Louisville Joint Stock Land Bank v. Radford, which invalidated the Frazier-Lemke $\mathrm{Act}^{47}$ as an unconstitutional taking of a mortgagee's rights in specific property acquired prior to the act, the Court enumerated five "substantive property rights" of which a secured creditor was held to be deprived under the act in question: (1) the right to retain the lien until the debt thereby secured is paid, (2) the right to realize upon the security by a judicial public sale, (3) the right to determine when such sale shall be held, subject only to the discretion of the court, (4) the right to protect his interest by bidding at such sale, and (5) the right to control the property during the period of default, subject only to the discretion of the court. The Frazier-Lemke Act provided for an appraisal of mortgaged farm property and allowed the mortgagor to retain possession for five years after default, during which period he might, at his option, purchase the property by payment to the mortgagee of the appraised value. The mortgagee was compensated for this delay by the payment of interest at the rate of only

their bonds on foreclosure does not limit power of bankruptcy court to sell free of liens).

There is a conflict of authority as to whether the court should exercise its power to sell free of liens where there is no equity in the property. See Oppenheim, Sales of Propcrty in Bankruptcy Free and Clear of Encumbrances (1934) 29 ILL. L. REv. 67, 77. And it is apparently the general practice not to order such a sale unless there is a fair prospect of an excess over the amount of the lien to be administered by the trustee. See Louisville Joint Stock Land Bank v. Radford, 295 U.S. 555, 583-4 (1935); In re Hasie, 206 Fed. 789, 792 (N.D. Tex. 1913). But it has been said that this is not a rule of law and is within the discretion of the Court. See In re Franklin Brewing Co., 249 Fed. 333, 335 (C.C.A. 2d, 1918).

44. Oilfields Syndicate v. American Improvement Co., 260 Fed. 905 (C.C.A. 9th, 1919).

45. 11 U. S. C. $\S 202$ (1935), held constitutional in In re Landquist, 70 F. (2d) 929 (C.C.A. 7th, 1934), cert. denied sub nom. Hardenbrook v. Landquist, 293 U.S. 584 (1934).

46. Under this statute it has been held that an extension agreement approved by the requisite majority is binding upon a non-assenting secured creditor who holds the only incumbrance on a particular piece of the debtor's property, and who, it seems, would be considered as in a class by himself for purposes of corporate reorganization. In re Sterba, 74 F. (2d) 413 (C.C.A. 7th, 1935).

47. 48 Stat. 1289,11 U. S. C. $\$ 203$ s (1934). 
one per cent or of a reasonable rental value of the property, and he had no assurance that the mortgagor would complete the purchase. The Radford case was the authority relied upon for holding Section $77 B(b)(5)(c)$ unconstitutional; $\mathbf{4 8}$ and while it is true that the Frazier-Lemke Act gave the mortgagee far less protection than does an immediate cash payment of the appraised value of his security, it is clear that the rights enumerated by the Court in the Radford case are taken from a secured creditor under subsection (b) (5)(c). The important distinction, however, lies in the practical difference between a farm mortgage and a corporate mortgage bond issue, especially as to the effect of a foreclosure sale on the creditor's security in each case, a distinction repeatedly recognized by the courts. 13

Mortgage bondholders in corporate reorganizations have been subjected to different treatment from that accorded to unitary holders of ordinary mortgages on farms or urban property. In an equity receivership the traditional right of a secured creditor to have the property sold at public sale and to bid at such sale to protect his interest survives as a fiction, for there is normally only one potential bidder, and the minority bondholders' technical right to bid is illusory. Under Sections 77 and $77 \mathrm{~B}$, even the form of the sale, the opportunity to bid, and the alternative right to cash payment, are taken from a minority bondholder by the provision requiring him to accept securities under a plan which has been accepted by two-thirds of his class and approved by the court. And although a dissenting secured creditor is thus deprived of his right to have the property sold at a public sale at which he may bid, these provisions apparently are constitutional. The Supreme Court in the Rock Island case gave strong indication that such a provision would be upheld, ${ }^{50}$ and subsequent decisions in the lower courts substantiate

48. It is interesting to note that the Circuit Court of Appeals for the Sixth Circuit, which decided the Tennessee Publishing Co. case, was the same Court that was reversed in the Radford case after holding the Frazier-Lemle Act valid. 74 F. (2d) 576 (C.C.A. 6th, 1935).

49. "The sale establishes the value, and any upset price whatever is a concession to the known uselessness of an action in such cases. If the upset price be too low, any creditor must protect himself by bidding. . . . So far as it has gone, the law has devised no other way to protect against what indeed in practice amounts to a strict foreclosure, except for the upset price. That judicial sales in such cases are of small value to creditors I cannot help; it results from applying the same procedure to the sale of a quarter section and a system of national transportation." Judge Leamed Hand in Equitable Trust Co. v. Western Pac. Ry., 244 Fed. 485, 504-5 (S.D.X.Y. 1917), aff'd, 250 Fed. 327 (C.C.A. 2d, 1918), cert. denied, 246 U.S. 672 (1918).

See also Louisville Trust Co. v. Louisville, N.A. \& C. Ry, 174 U.S. 674, 683 (1899) ; Geddes v. Anaconda Copper Mfining Co., 254 U.S. 590, 601-2 (1921) : Mlechanies' and Metals' Nat. Bank v. Howell, 207 Fed. 973, 981 (D. Conn. 1913). Katz, Protcetion of Minority Bondholders in Foreclosures and Recciverships (1936) 3 U. or Cnr. L. REv. 517.

50. See 294 U.S. 648,674 (1935). 
that conclusion. ${ }^{51}$ While this affords no direct support for the proposition that the court may be empowered to bind dissenting creditors to take an appraised value of their claims, in the absence of approval by two-thirds of the class affected, it does serve to show that the substantive property rights of secured creditors enumerated in the Radford case are not entirely inviolable under the Constitution. For under the Rock Island case and subsequent decisions, a dissenting secured creditor is deprived of all five of the rights catalogued in the Radford case. Since these rights of a secured creditor may constitutionally be altered when the requisite two-thirds of his class has consented, the crucial issue appears to be the constitutional significance of approval by two-thirds of a class.

The lack of the consent of a substantial number of the class of secured creditors may well be considered a stumbling block of considerable importance in view of the history of composition and adjustment legislation. Since such statutes in both England and the United States have hitherto consistently adhered to the principle of majority rule, ${ }^{52}$ direct precedents are lacking. It has been argued, however, that under the circumstances of most modern reorganizations the consent of two-thirds of a class reflects the vigor of protective committees in soliciting proxies rather than a considered judgment by security holders, and therefore that the absence of a two-thirds approval should not alone influence the judge to declare the plan unfair. ${ }^{63}$ It would seem that the absence of such consent will serve as a warning to the judge and that the finding of the Court that the plan is fair and equitable to all, made in the light of that warning, is adequate protection for the interests of the creditors. As for the-right of a dissenting class to cash payment, there are good practical reasons to suppose that an appraised value will normally be higher than an upset price, ${ }^{54}$ for the emphasis in appraisal is shifted from the necessity of selling the property to a separate consideration of the claims of the dissenting class who are thus in an excellent strategic position to exert pressure. And the possibility of forcing dissenters to take securities under the plan by setting the appraised value

51. Campbell v. Alleghany Corp., 75 F. (2d) 947 (C.C.A. 4th, 1935), cert. denied, 296 U. S. 581 (1935) ; In re Central Funding Corp., 75 F. (2d) 256 (C. C. A. 2d, 1935); In re Hotel Gibson Co., 11 F. Supp. 30 (S. D. Ohio, 1935).

52. The English composition statutes require consent of a majority in number and three-fourths in amount, 4 \& 5 Geo. V, c.59, $\$ 16$ (1914); the Canadian Bankruptcy Act requires a majority in number and two-thirds in amount, 9 \& $10 \mathrm{Geo}$. V, c.36, $\$ 13$ (1920); and the Australian Act requires a majority, Bankruptcy Act, 1924-28, \$71. The reorganization provisions of the English Companies Act of 1929 require a majority in number and three-mourths in amount, $19 \& 20 \mathrm{Geo}$. V, c. 23, §153 (1930).

53. Cf. Frank, supra note 20, at 711-12; Spaeth and Friedberg, Early Developments under Section $77 B$ (1935) 30 ILL. L. REv. 137, 176.

54. See 2 Gerdes, Corporate Reorganizations (1936) \$1067; Frank, supra note 20 , at 557, 713-14; Sabel, supra note 24, at 58; Wehle, supra note 19, at 219-20. 
lower than the cash value of the securities offered is eliminated by the option given to the creditor in subsection (b)(5)(c) to take the cash value of the latter. It is true that a secured creditor under the subsection is deprived of the right to bid in the property at the sale and to hold it until such time as values may be restored, and this right may have considerable value in the hands of first mortgage bondholders. A substitute of comparable value, however, is provided in the opportunity to retain an interest in the property through participation in a plan which has been approved as fair by the court. Another circumstance to be considered is the fact that, in a case to which subsection (b) (5) (c) is properly applicable, other classes of security holders are also interested in the property, so that the non-assenting group may well be a minority of the whole number of interested creditors; and the court should not be precluded from dealing with the property and the creditors as a single group, in a manner which it finds to be for the best interests of all, simply because part of a class, majority or minority, refuses to consent to a "fair" plan.5s

Furthermore, it seems that the doctrine of the Boyd case would apply to reorganizations through the Bankruptcy Act as well as those accomplished in any other way. ${ }^{56}$ The implications of that doctrine would require that first mortgage bondholders or other senior lien-holders be paid the face value of their claims, or nearly so, before a plan recognizing interests in junior creditors and stockholders could properly be approved. This requirement, as applied to the questions of fairness of the plan and the amount of the appraised value to be paid, would serve as a limitation upon the use of subsection (b) (5) (c) as a means of putting through a plan without the consent of prior classes, and would seem to provide adequate protection for their interests. Accordingly, it would seem more desirable to leave subsection (b) (5) (c) on the statute books as a discretionary means for dealing with recalcitrant classes whose object is obstruction, and to apply the Boyd doctrine as a protection for the interests of senior creditors.

Conclusion. The validity of subsection (b)(5)(c) as a matter of due process must be tested by balancing the rights of creditors, reasserted in the Radford case, against the discretionary power which a court requires for the efficient administration of a corporate reorganization. When compared to its accepted alternative in equity receivership, subsection (b) (5) (c) seems an unsubstantial change in creditors' rights, which may contribute much to the efficacy of reorganization procedure. Courts should not find

55. See Friendly, supra note 5 , at 35-6.

56. See In re New York Railways Corp., 82 F. (2d) 739, 744 (C. C. A. 2d, 1936), cert. denied, 56 S. Ct. 959 (1936) ; Frank, supra note 20, at 608; Cf. Swaine, Reorgossization-The Next Step: $A$ Reply to Mr. James $N$. Rosenberg in Conporatz Reonganiization aNd the Federat Court (1924) 104; Kingston v. Ameriean Car \& Foundry Co., 55 F. (2d) 132 (C.C.A. 8th, 1932). 